\title{
Ambient Fine Particulate Matter Induces Apoptosis of Endothelial Progenitor Cells Through Reactive Oxygen Species Formation
}

\author{
Yuqi Cui ${ }^{a}$ Xiaoyun Xie ${ }^{a}$ Fengpeng Jia ${ }^{a}$ Jianfeng $\mathrm{He}^{\mathrm{a}}$ Zhihong $\mathrm{Li}^{\mathrm{a}}$ \\ Minghuan Fu ${ }^{a}$ Hong Hao ${ }^{a}$ Ying Liu ${ }^{a}$ Jason Z. Liu ${ }^{a}$ Peter J. Cowan ${ }^{c}$ \\ Hua Zhua,b Qinghua Sun ${ }^{\mathrm{a}}$ Zhenguo Liu ${ }^{\mathrm{a}}$
}

aDorothy M. Davis Heart and Lung Research Institute, Division of Cardiovascular Medicine, bDepartment of Surgery, The Ohio State University Wexner Medical Center, Columbus, OH, USA; 'Department of Medicine, University of Melbourne, St. Vincent's Hospital, Melbourne, Australia

\section{Key Words}

PM • Endothelial progenitor cells $•$ ROS • Apoptosis

\begin{abstract}
Background/Aims: Bone marrow (BM)-derived endothelial progenitor cells (EPCS) play a critical role in angiogenesis and vascular repair. Some environmental insults, like fine particulate matter (PM) exposure, significantly impair cardiovascular functions. However, the mechanisms for PM-induced adverse effects on cardiovascular system remain largely unknown. The present research was to study the detrimental effects of PM on EPCs and explore the potential mechanisms. Methods: PM was intranasal-distilled into male C57BL/6 mice for one month. Flow cytometry was used to measure the number of EPCs, apoptosis level of circulating EPCs and intracellular reactive oxygen species (ROS) formation. Serum TNF- $\alpha$ and IL-1 $\beta$ were measured using ELISA. To determine the role of PM-induced ROS in EPC apoptosis, PM was co-administrated with the antioxidant $\mathrm{N}$-acetylcysteine (NAC) in wild type mice or used in a triple transgenic mouse line (TG) with overexpression of antioxidant enzyme network (AON) composed of superoxide dismutase (SOD)1, SOD3, and glutathione peroxidase (Gpx-1) with decreased in vivo ROS production. Results: PM treatment significantly decreased circulating EPC population, promoted apoptosis of EPCs in association with increased ROS production and serum TNF- $\alpha$ and IL-1 $\beta$ levels, which could be effectively reversed by either NAC treatment or overexpression of AON. Conclusion: PM exposure significantly decreased circulating EPCs population due to increased apoptosis via ROS formation in mice.
\end{abstract}

Copyright (C 2015 S. Karger AG, Basel

Zhenguo Liu, MD, PhD

KARGER 125
Davis Heart \& Lung Research Institute, The Ohio State University Wexner Medical Center Room 200 DHLRI 473 West $12^{\text {th }}$ Ave Columbus, OH 43210 (USA)

Tel. +1614247-8435; E-Mail zhenguo.liu@osumc.edu 


\section{Cellular Physiology and Biochemistry}

Cell Physiol Biochem 2015;35:353-363

\begin{tabular}{l|l}
\hline DOI: $10.1159 / 000369701$ & (C) 2015 S. Karger AG, Basel
\end{tabular}

Cui et al.: PM Impairs EPC via ROS Production

\section{Introduction}

Endothelial dysfunction or injury is considered one of the major factors that contribute to the development of cardiovascular diseases like atherosclerosis and coronary heart disease $[1,2]$. Endothelial progenitor cells (EPCs) play a critical role in vascular re-endothelialization, angiogenesis, and prevention of neointima formation after vascular injury [3-5]. Therefore, it is important to maintain the number and function of EPCs to normal level in pathological conditions, such as hyperlipidemia and diabetes.

A recent Global Burden of Disease Study suggested that the ambient fine particulate matter (PM) is responsible for 3.2 million deaths per year and 76 million years of healthy life lost [6]. The majority of mortality following PM exposure has been shown to be related to cardiovascular diseases [6]. Different sources of PM contain different components. The composition of PM is a mixture of various particles including metals, crustal material and bioaerosols [7, 8]. It has been reported that PM exposure is able to produce many deleterious effects on cardiovascular system such as vascular dysfunction, reduced heart rate variability and enhanced coagulation-thrombosis risk [7, 9]. Long-term exposure of PM accelerated the process of atherosclerosis and vascular inflammation in apolipoprotein $\mathrm{E}$ knockout (apoE $\mathrm{E}^{-/}$) mice with high fat diet [10]. Recent studies have found that PM significantly suppressed the number and function of EPCs in both mouse and human $[11,12]$. However, the mechanisms for the detrimental effects of PM on EPCs remain largely unknown.

It has been shown that exposure to PM leads to increased production of reactive oxygen species (ROS) and oxidative stress [13]. The present study was designed to test the hypothesis that increased ROS formation could mediate the effect of PM on the population of circulating EPCs. We first demonstrated that PM indeed significantly decreased the EPC populations in peripheral blood in association with increased level of serum TNF- $\alpha$ and IL-1 $\beta$ and increased apoptosis of EPCs. To further test the hypothesis that ROS induced by PM was the main cause for EPCs apoptosis, ROS production was blocked by using either antioxidant $\mathrm{N}$-acetylcysteine (NAC) or a transgenic mouse model (TG) with concomitant overexpression of an antioxidant enzyme network (AON) of human copper/zinc superoxide dismutase (SOD)1, extracellular SOD3, and glutathione peroxidase (Gpx-1) with decreased ROS formation. We observed that NAC treatment or AON overexpression could effectively rescue PM-induced EPCs apoptosis. Taken together, our data demonstrated that PM-mediated ROS production was indeed the major cause for increased apoptosis of EPCs, thus, preventing excessive ROS formation might be a potential effective approach to the prevention and treatment of PMinduced cardiovascular disorders.

\section{Materials and Methods}

\section{PM exposure and animal model}

All the animal experiments were performed in accordance with the Guidelines of the Animal Care Committee of the Ohio State University Medical Center, Columbus, Ohio, USA. The experimental protocols for the present study were reviewed and approved by the Animal Care Committee of the Ohio State University Medical Center. PM $<4 \mu \mathrm{m}$ (Standard Reference Materials 2786) was purchased from The National Institute of Standards and Technology (NIST), which has a mean particle diameter of $2.8 \mu \mathrm{m}$ (particle-size characteristics in atmospheric particulate material and similar matrices) with the major components including polycyclic aromatic hydrocarbons (PAHs), nitro-substituted PAHs (nitro-PAHs), polybrominated diphenyl ether (PBDE) congeners, hexabromocyclododecane (HBCD) isomers, sugars, polychlorinated dibenzo-p-dioxin (PCDD) and dibenzofuran (PCDF) congeners, and inorganic constituents [14]. PM was dispersed in solution by ultrasonication in endotoxin-free PBS for $30 \mathrm{~min}$ at a concentration of $0.5 \mu \mathrm{g} / \mu \mathrm{l}$ [15]. Each mouse was treated with10 ug PM three times per week for 1 month via intranasal instillation that has been widely used and validated as described [16-19]. Endotoxin-free PBS was used as control. Wild-type (WT) male C57 BL/6 mice (6-8 weeks old) were purchased from Jackson Lab (Maine, USA). To evaluate the role of ROS formation induced by PM, the mice were pre-treated with NAC $(1 \mathrm{mg} / \mathrm{ml}$ in the drink 


\section{Cellular Physiology and Biochemistry}

Cell Physiol Biochem 2015;35:353-363

\begin{tabular}{l|l}
\hline DOI: $10.1159 / 000369701$ & (C) 2015 S. Karger AG, Basel
\end{tabular}

www.karger.com/cpb

water) for 24 hours prior to PM exposure. To further evaluate the role of ROS production in mediating the effects of PM, a TG mouse model with concomitant overexpression of AON with decreased ROS production (6-8 weeks old, male) were used to repeat the experiment. The generation of TG mouse that have been backcrossed at least 10 generations onto the C57 BL/6 background was detailed previously [20]. The AON enzyme overexpression level and their activities were also determined recently [21], and confirmed in the present study. The littermate WT male C57BL6 mice were used as the control.

Histological examination of lung sections

To assess the effects of PM on airway inflammation, lungs were excised and fixed in $10 \%$ formalin, washed in methanol, dehydrated, embedded in paraffin, and cut into 5- $\mu \mathrm{m}$ sections. The preparations were then mounted on slides, stained with hematoxylin and eosin, and examined microscopically in a blinded fashion.

Proinflammatory cytokines measurement

Mouse blood was collected after 1 month of exposure to PM. The serum was prepared from the blood sample with centrifugation for 20 minutes at $300 \mathrm{~g}$. The levels of serum proinflammatory cytokines TNF- $\alpha$ and IL-1 $\beta$ were determined using ELISA kit from Biolegend (San Diego, CA, USA) according to manufacturer's recommendation.

Flow cytometry analysis for cell apoptosis, intracellular ROS formation and EPCs

After exposure of mice to PM or PBS for 1 month, mouse blood was collected and the red blood cells (RBC) were eliminated with RBC-lysis buffer as described [22]. The blood cell apoptotic rate was determined with FACS using the apoptosis kit from BD Pharmingen (CA, USA). The early apoptotic cells were defined as Annexin V FITC positive cells, while the late apoptotic cells was defined as Annexin V FITC and propidium iodide (PI) double positive cells as described [23]. The level of intracellular ROS formation in blood cells was determined using the ROS Detection Reagents-FITC (Invitrogen) as described [22]. The cells were incubated with the reagent for $10 \mathrm{~min}$ at $37^{\circ} \mathrm{C}$. The labeled cells were washed twice with PBS and then suspended in warm PBS for analysis using flow cytometry. The fluorescence-positive cells were quantitatively evaluated using an LSRII (BD Bioscience, CA, USA) at the wavelength of $525 \mathrm{~nm}$ as described [22]. For the circulating EPC analysis, the blood $\mathrm{CD} 34^{+} / \mathrm{CD} 133^{+}$cell population was determined using flow cytometry as described [24] with a total of 50,000 cells used for each test. The antibody CD34+ AF700 was obtained from Becton Dickinson Biosciences (NJ, USA), and CD133+ PE was from Biologend (San Diego, CA, U.S).

\section{Statistical Analysis}

All the data were presented as means \pm standard deviation (SD), and statistically analyzed using unpaired Student t-test (two-sided) for two groups of data or one way ANOVA (analysis of variance) (PRISM Version 4.0; GraphPad Software, Inc., San Diego, CA) followed by post hoc conservative Tukey's test for three or more groups of data to minimize type I error as appropriate. The differences were considered statistically significant when a two-tailed $\mathrm{p}<0.05$.

\section{Results}

PM treatment decreased circulating EPC number in association with increased apoptosis

Blood cells were collected for EPC analysis after PM exposure. Flow cytometry analysis showed that PM exposure significantly decreased the population of $\mathrm{CD} 34^{+} / \mathrm{CD} 133^{+}$cell by $50 \%$ as compared to the control group (Fig. 1A). In search for the reason for EPC suppression by PM, the blood cell apoptotic rate was determined. As shown in Fig. 1B, the early apoptosis rate of circulating EPCs was significantly increased up to $17 \%$ compared to the rate of $9 \%$ in control group. In addition, the late apoptosis rate was also substantially increased up to 3 folds over the control group (Fig. 1C).

PM treatment increased the serum levels of TNF- $\alpha$ and $I L-1 \beta$ and induced inflammation infiltration in the lung

TNF- $\alpha$ and IL-1 $\beta$ are closely related to cell apoptosis $[25,26]$ and upregulated by PM exposure [27]. To explore the mechanisms for increased EPC apoptosis induced by PM, 


\section{Cellular Physiology \\ and Biochemistry}

Cell Physiol Biochem 2015;35:353-363

DOI: 10.1159/000369701

Publisned online: Janury 12, 2015

(C) 2015 S. Karger AG, Basel

Cui et al.: PM Impairs EPC via ROS Production

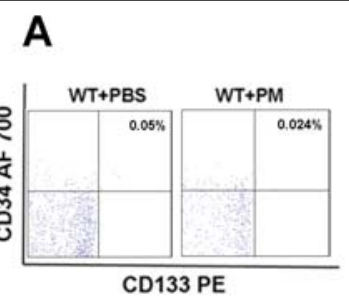

B

C
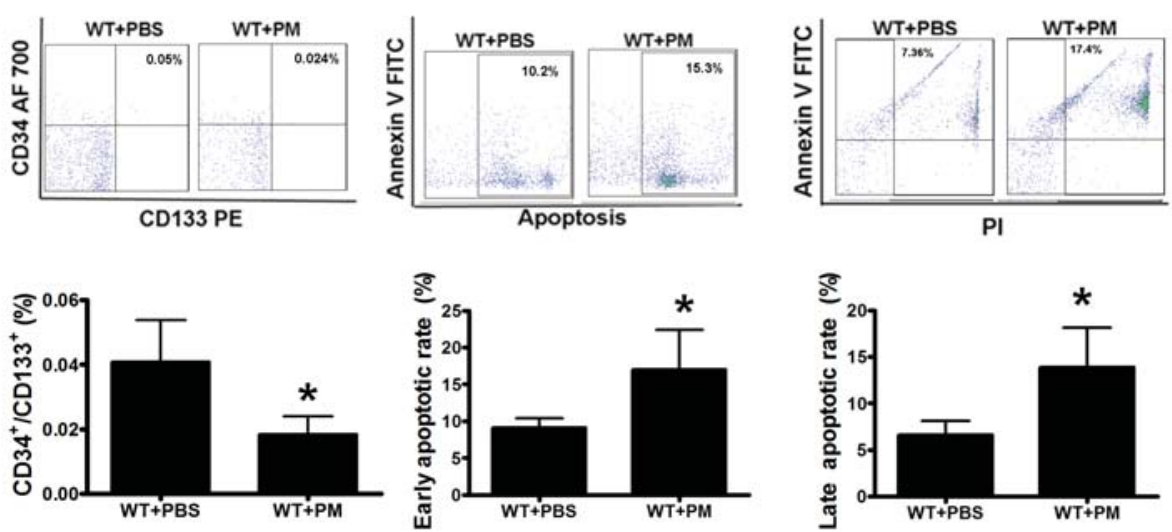

Fig. 1. PM treatment decreased murine circulating EPC level with increased EPC apoptosis. A. After exposure of C57BL/ 6 mice with PM or PBS through intranasal distillation for 1 month, the blood cells were collected after red blood cell lysis and stained with CD34-AF700 and CD133-PE antibody for EPC (CD34 $\left.{ }^{+} / \mathrm{CD}_{133^{+}}\right)$ measurement. The EPC level was significantly decreased in C57BL/6 mice with PM exposure compared to the PBS control. The annexin V (B) and PI (C) were used to incubate the blood cells for apoptosis analysis. Both early (B) and late (C) apoptotic rate of blood cells in the mice with PM exposure was significantly increased as compared to the PBS control group. WT+PBS: C57BL/6 mice with PBS treatment; WT+ PM: C57BL/6 mice with PM exposure. * WT+ PM vs WT+PBS, P<0.01, n=8.

Fig. 2. PM increased the levels of serum proinflammatory cytokines and induced lung inflammation infiltration. The murine serum was prepared for proinflammatory cytokine TNF- $\alpha$ and IL- $1 \beta$ measurements, and lung was collected for inflammation infiltration analysis after exposure in C57BL/6 mice with PM or PBS for 1 month. There was a significant increase in both TNF- $\alpha(\mathrm{A})$ and IL-1 $\beta$ (B) in the serum in the mice with PM exposure compared with the PBS control. The inflammation level was significantly increased in murine lung with PM exposure. WT+PBS: C57BL/6 mice with PBS treatment; WT+ PM: C57BL/6 mice with PM exposure. * $\mathrm{WT}+\mathrm{PM}$ vs $\mathrm{WT}+\mathrm{PBS}$ $\mathrm{P}<0.01, \mathrm{n}=8$.

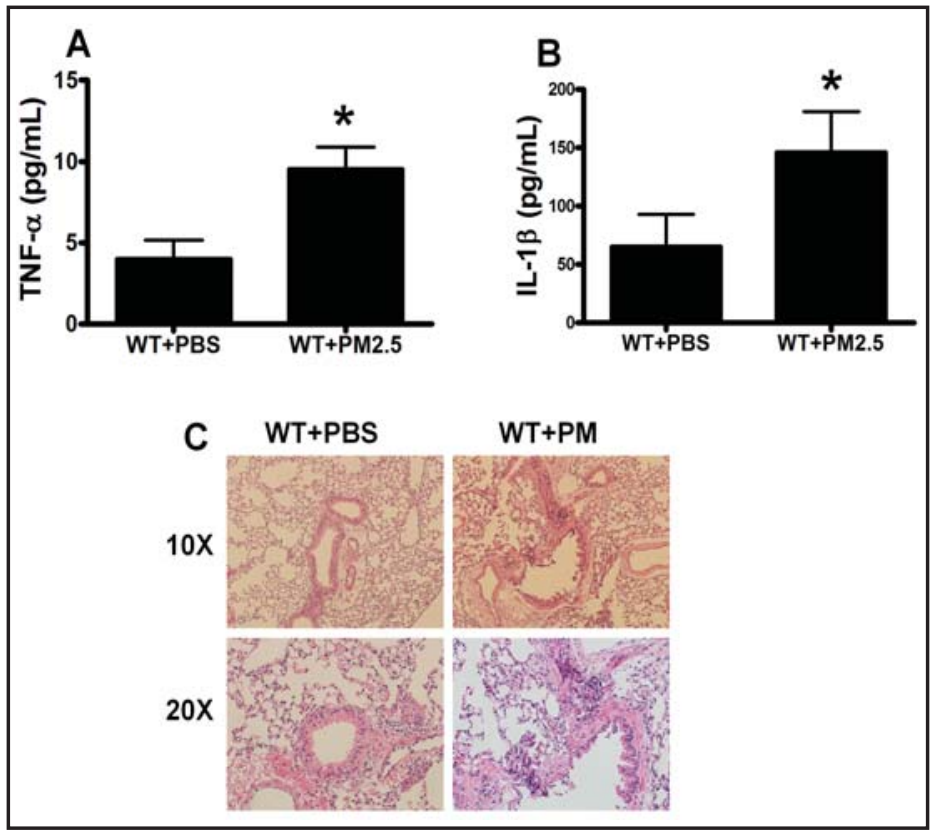

serum levels of TNF- $\alpha$ and IL-1 $\beta$ were measured. The serum levels of the inflammatory factors TNF- $\alpha$ and IL- $1 \beta$ were significantly elevated to $9 \mathrm{pg} / \mathrm{ml} \pm 1.8 \mathrm{pg} / \mathrm{ml}$ and $156.9 \mathrm{pm} / \mathrm{ml}$ $\pm 37.8 \mathrm{pg} / \mathrm{ml}$ in the mice with PM exposure compared to $4.3 \mathrm{pm} / \mathrm{ml} \pm 1.1 \mathrm{pg} / \mathrm{ml}$ and $69.8 \mathrm{pg} /$ $\mathrm{ml} \pm 25.1 \mathrm{pg} / \mathrm{ml}$ in the mice with PBS treatment, respectively (Fig. 2A and B). To determine if the increased serum levels of TNF- $\alpha$ and IL- $1 \beta$ were associated with tissue inflammation, we examined the inflammation infiltration in the lung. Indeed, after exposure with PM for 1 month, the inflammation infiltration of mouse lung was induced compared to the PBS control (Fig. 2C). 


\section{Cellular Physiology Cell Physiol Biochem 2015;35:353-363

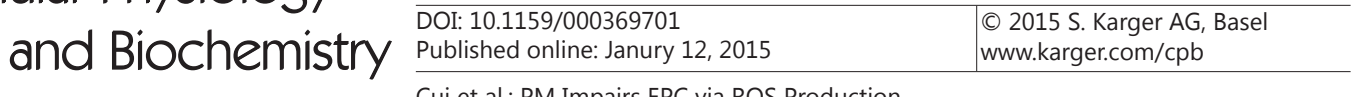

Fig. 3. PM induced ROS production in association with increased apoptosis of EPCs. Intracellular ROS production was quantitatively determined using the ROS Detection Reagents-FITC in the blood mononuclear cells. Intracellular ROS formation was significantly increased in the wild type mice with PM exposure. WT+PBS: C57BL/6 mice with PBS treatment; WT+ PM: C57BL/6 mice with PM exposure. * WT+PM vs WT+PBS, $\mathrm{P}<0.001, \mathrm{n}=8$.

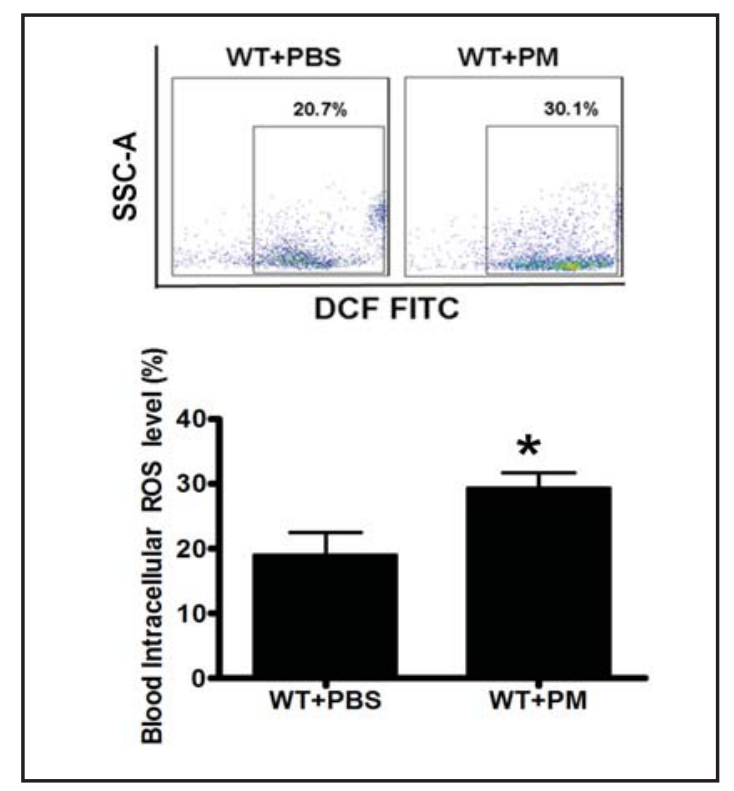

PM increased intracellular ROS production in circulating EPCS

ROS production could induce proinflammatory cytokine secretion [28]. Thus, we hypothesized that PM-induced proinflammatory cytokine secretion might be through ROS production. We observed that intracellular ROS level was indeed significantly increased in the circulating EPCs in the mice with PM exposure (Fig. 3).

NAC treatment or AON overexpression attenuated the detrimental effects of PM on EPCs

To determine whether ROS was the cause for EPC apoptosis induced by PM, both pharmacological and transgenic approaches were employed to block ROS generation. When the WT-mice were co-treated with PM and NAC, ROS formation was effectively inhibited. We also used a transgenic (TG) mouse model that over-expressed AON with reduced ROS production. We observed that blood intracellular ROS production induced by PM exposure was effectively blocked in NAC-treated mice and in the TG mice overexpressing the AON (Fig. 4A).

To determine whether the increased serum proinflammatory cytokine level and inflammation infiltration in the lung in the mice exposed to PM were mediated by ROS, the lung tissue inflammation infiltration and the serum TNF- $\alpha$ and IL-1 $\beta$ levels were evaluated in NAC-treated mice and in TG mice. Consistent with our hypothesis, the TNF- $\alpha$ and IL-1 $\beta$ levels were reversed to the normal level in the mice exposed to PM and treated with NAC or over-expressing AON compared to their controls (Fig. 4B and 4C). In addition, murine lung inflammation infiltration level was significantly decreased in TG mice or NAC-treated WT mice (Fig. 4D). These data suggested that increased serum proinflammatory cytokine level and lung inflammation infiltration in the mice exposed to PM were indeed mediated by increased ROS formation.

Next, we determined whether NAC treatment or over-expressing AON could prevent PM-induced EPC apoptosis. As expected, both early and late apoptotic rate ( $17 \%$ for early apoptotic and $14 \%$ for late apoptotic rate after PM treatment) of EPCs were significantly reversed in either NAC treated mice or TG mice following PM exposure (Fig. 4E and F).

Finally, we examined whether inhibition of ROS production could maintain EPC population during PM exposure. As shown in Fig. 4G, decreased EPC population by PM was completely reversed by NAC treatment or AON overexpression. Thus, our data suggested that ROS induced by PM exposure was indeed a major cause for decreased population of circulating EPCs due to increased apoptosis. 


\section{Cellular Physiology $\quad$ Cell Physiol Biochem 2015;35:353-363 \\ \begin{tabular}{l|l|l}
\hline DOI: 10.1159/000369701 & O 2015 S. Karger AG, Basel
\end{tabular} \\ and Biochemistry Published online: Janury 12, 2015}

Fig. 4. NAC treatment or AON overexpression decreased ROS production and reversed the detrimental effects of PM. (A) Increased blood intracellular ROS production was effectively blocked by NAC treatment or AON overexpression in the mice exposed with PM. The murine lung inflammation was much lower in TG mouse and WT mouse with NAC treatment than the WT mouse with PM exposure. Increased level of serum proinflammatory cytokine TNF- $\alpha$ (B) and IL-1 $\beta$ (C) as well as lung inflammation infiltration (D) was significantly decreased by NAC treatment or AON overexpression in the mice exposed with PM. Increased early apoptotic (E) and late apoptotic $(\mathrm{F})$ rate were effectively reversed by NAC treatment or AON overexpression in the mice exposed with PM. (G) Decreased circulating EPC level was completely restored by NAC treatment or AON overexpression in the mice exposed with PM. WT+PBS: C57BL/6 mice with $\mathrm{PBS}$ treatment; WT+ PM: C57BL/6 mice with PM exposure; WT+ PM+NAC: $\mathrm{C} 57 \mathrm{BL} / 6$ mice with PM exposure and NAC treatment; $\mathrm{TG}+\mathrm{PM}$ : TG mouse with PM exposure. * WT+PM vs WT+PBS or $\mathrm{WT}+\mathrm{PM}+\mathrm{NAC}$ or $\mathrm{TG}+\mathrm{PM}$. $\mathrm{P}<0.01, \mathrm{n}=8$.
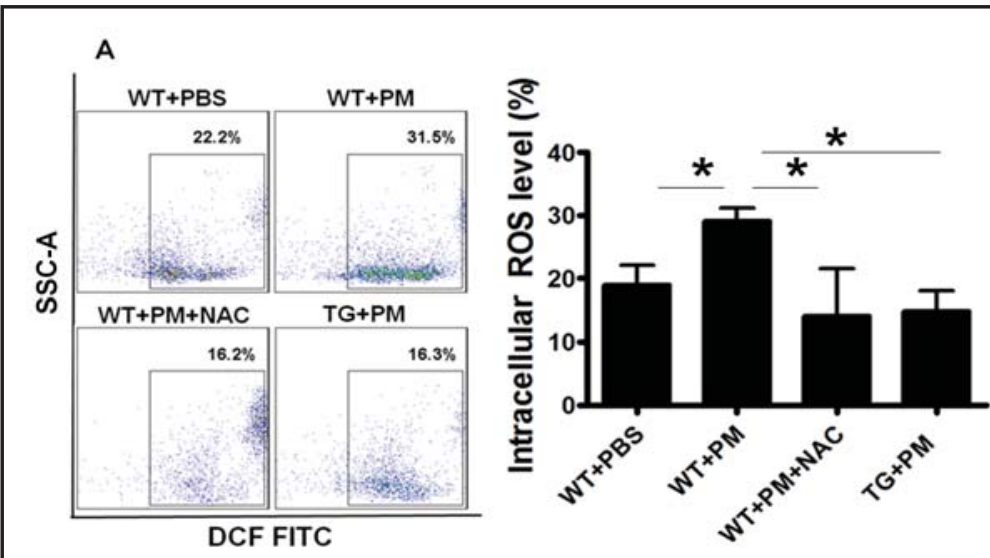

B
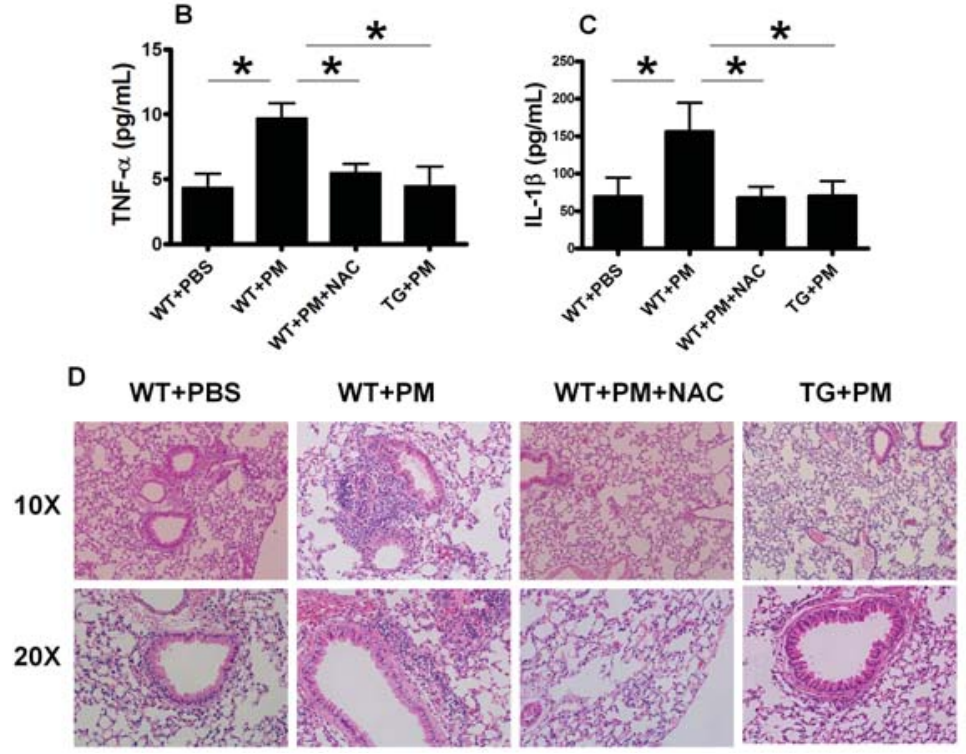

E
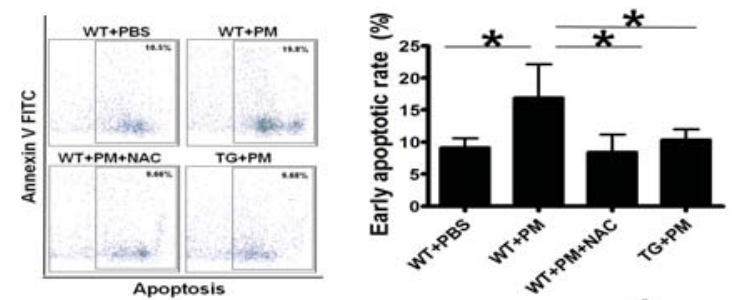

F
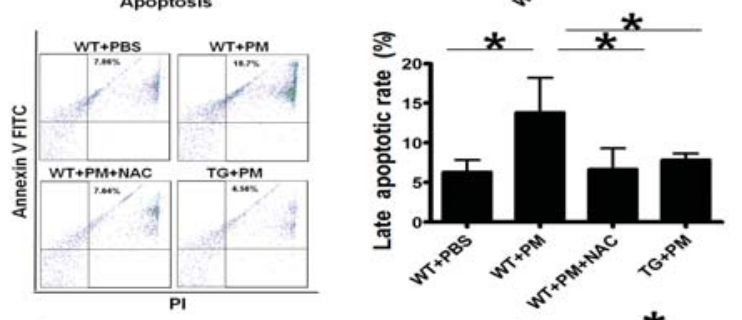

G

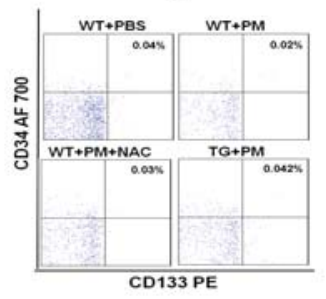




\section{Cellular Physiology and Biochemistry}

Cell Physiol Biochem 2015;35:353-363

DOI: 10.1159/000369701

Publisned online: Janury 12, 2015

Cui et al.: PM Impairs EPC via ROS Production
Fig. 5. Illustration of possible mechanisms for decreased number of circulating EPCs in the mice with PM exposure. PM exposure increased blood intracellular ROS production and inflammatory cytokine level. Blood cell apoptotic rate was then significantly increased, and the circulating EPC number was notably decreased which could contribute to the development of atherosclerosis and other cardiovascular diseases. NAC or AON attenuated the PM-induced ROS formation and decreased serum inflammatory cytokine level and apoptotic rate of EPCs. The circulating EPC number was significantly recovered with NAC treatment or AON overexpression in the mice exposed to PM. PM: particulate matter; ROS: reactive oxygen species; EPC: endothelial progenitor cell; AON: antioxidant enzyme network; NAC: N-acetylcysteine; $\uparrow$ : increase; $\downarrow$ : decrease.

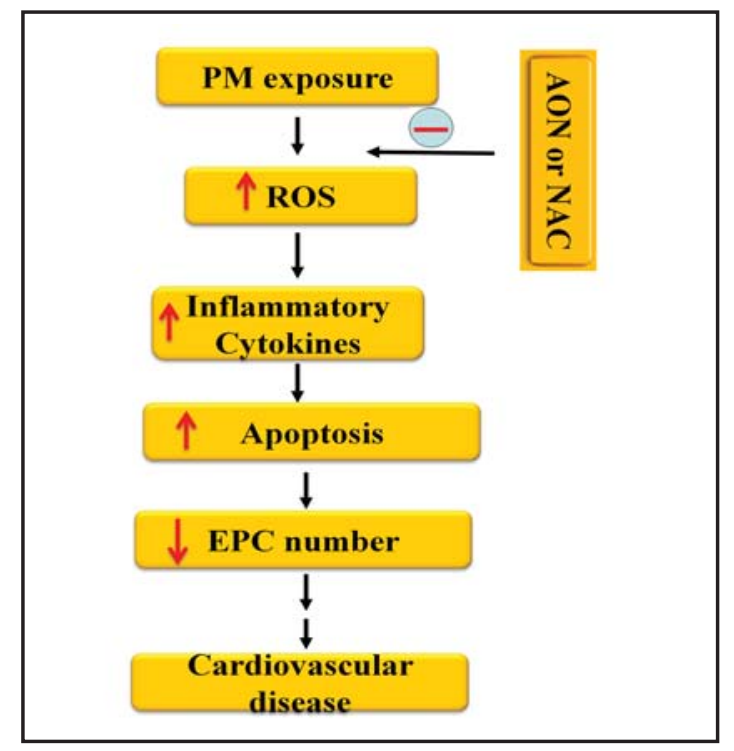

\section{Discussion}

In the present study, we demonstrated that PM exposure significantly decreased the circulating EPC population through proinflammatory cytokine TNF- $\alpha$ and IL-1 $\beta$ mediated apoptosis. We further demonstrated that treating the mice with antioxidant NAC or overexpression of AON significantly decreased the intracellular ROS level in circulating EPCs, reduced serum TNF- $\alpha$ and IL-1 $\beta$ level, diminished EPC apoptotic rate, and restored EPC population in the mice with PM exposure. To our knowledge, this was the first time to report that PM-induced ROS production was responsible for the impaired number of EPCs through ROS-TNF- $\alpha$ / IL-1 $\beta$-apoptotic pathway as shown in Fig. 5.

Air pollution or second hand smoke (SHS) has significant impact on the number and function of EPCs. Some studies have shown that SHS, PM and other pollutants such as nickel and acrolein are able to decrease the number and function of circulating EPCs [11,29]. The potential mechanisms are believed to be related to impaired VEGF-mediated signaling that compromised the mobilization of bone marrow-derived EPCs to the circulation [30] or blocking nitric oxide production [31]. On the other hand, SHS has been shown to increase EPC level through increased VEGF and MCP-1 level [32]. Some clinical studies demonstrated, that brief inhalation of coarse PM [12] or SHS [31] could increase the number, but decrease the function of EPCs. However, O'Toole et al. reported that exposure of higher concentration of PM (for 24 hours) could lead to a reduction in circulating EPCs in young adults [33]. Further studies are required to dissect the detailed molecular mechanisms to clarify the conflicting observations.

ROS and oxidative stress are involved in EPC dysfunction in many disease states including hyperlipidemia, diabetes and coronary artery disease [3-5]. Particles especially PM widely exist in the environment and may carry ROS within gas phase [13] or water phase (aerosol) [34] into the lower respiratory tract to create an increased risk on health. There is growing evidence for oxidative stress in response to air pollution in different organs [35]. ROS could function as signaling molecules in PM-trigged autophagy in human epithelia A549 cells [36]. Oxidative stress could be triggered by PM and result in alterations in mitochondrial gene expression in brown adipose tissue [37]. Clinical studies indicated that ROS-initiated oxidative stress and inflammation by PM was closely related to the pediatric asthma [38]. Tonne et al. described a relationship between ambient $\mathrm{PM}_{10}$, oxidative burden and carotid intima-media thickness (a measure of subclinical atherosclerosis) [39]. PM extracts could deplete antioxidants from a simulated respiratory tract lining fluid model which contained three major water soluble antixoidants (glutathione, urate, and ascorbate) at physiological 


\section{Cellular Physiology and Biochemistry}

Cell Physiol Biochem 2015;35:353-363

DOI: 10.1159/000369701

Publisned onIIne: Janury 12, 2015

Cui et al.: PM Impairs EPC via ROS Production

concentrations that served as the first line defense in the airway against the oxidative activity of PM [40]. In addition, Strak et al. delineated that PM- and $\mathrm{PM}_{10}$-related oxidative burden did not have an important impact on acute changes in exhaled NO or lung function, while a close relationship was present for ultrafine particles and NO2/NOx [41]. These observations were consistent with our hypotheses that ROS production might be a major cause of decreased number of EPCs following PM exposure.

The role of inflammatory cytokine-induced ROS production in apoptosis has been established [42]. ROS could also directly induce inflammatory cytokine expression/ production via regulation of immune signaling through TLR4-mediated NF- $\mathrm{BB}$ activation [28]. It was reported that the $\mathrm{Mn}^{2+}$-mediated induction of inflammatory cytokine production was associated with increased production of $\mathrm{H}_{2} \mathrm{O}_{2}$, and effectively attenuated by the $\mathrm{H}_{2} \mathrm{O}_{2}$ scavenger dithiothreitol, and partially prevented by inhibitors of NF- $\mathrm{KB}$ and p38MAP kinase [43]. ROS has been shown to induce gene expression of inflammatory mediators, such as IL-1 and TNF-a [44]. Inflammatory cytokines have significant effect on nearly all cell types including EPCs through their receptors (which are ubiquitously present on nearly all cell types), and p75-related TNF receptor that is predominantly expressed in lymphoid cells as well as other hematopoietic and endothelial lineage cells like EPCs [45]. In the present study, we demonstrated that PM exposure induced ROS production that increased TNF- $\alpha$ and IL-1 $\beta$ level, thus leading to increased apoptosis of EPCs.

Antioxidant enzyme and antioxidant supplementation have been examined for its impact on cardio-respiratory effects of PM exposure. Animal studies have shown an increase in the levels of antioxidant gene expression in epithelial cells after exposure to diesel exhaust particles [46]. Romieu et al. [47] reported that omega-3 polyunsaturated fatty acid blunted the adverse effect of PM on heart rate variability. Additionally, Tashakkor et al. demonstrated that antioxidant supplementation such as Vitamin C and E had multiple beneficial and protective effects against the damage of different air pollution on human lung [48]. Antioxidant probucol and vitamins were able to rescue cigarette smoke-dependent impairment of ischemia-induced neovascularization via improvement of EPC function [49]. However, to date, no study has linked the beneficial effects of antioxidant treatments to EPC survival. The present study illustrated that either antioxidant NAC or overexpression of AON was able to decrease serum TNF- $\alpha$ and IL- $1 \beta$ level, reduce EPC apoptotic rate, and in turn, maintain EPCs level in the mice exposed to PM.

Of course, there are lots of questions that need to be addressed on PM-induced structural and functional impairment on EPCs. For example, does PM also affect bone marrow stem cells which are the main source of EPCs? Does PM affect the proliferation of EPCs in addition to induce apoptosis? Does PM also trigger autophagy of EPCs? Does PM induce other inflammatory factors to alter the EPC population? How does ROS regulate the production and secretion of TNF- $\alpha$ and IL-1 $\beta$ ? What are the source of TNF- $\alpha$ and IL- $1 \beta$ following PM treatment? All these questions require further studies.

In conclusion, we reported that PM exposure significantly decreased circulating EPC population through enhanced ROS-TNF- $\alpha$ and IL-1 $\beta$-apoptosis pathway, and the antioxidant NAC or overexpression of AON was able to reverse the adverse effect of PM on EPCs. These findings suggested that preventing excessive ROS production could constitute a novel therapeutic strategy to treat cardiovascular diseases associated with air pollution.

\section{Disclosure Statement}

The authors declare no conflict of interest.

\section{Acknowledgements}

This work was supported by a US NIH grants NIH R01 HL094650 (to ZL), R01ES018900 (QS), and an American Heart Association grant to HZ (AHA 12SDG12070174) 


\section{Cellular Physiology and Biochemistry}

Cell Physiol Biochem 2015;35:353-363

\begin{tabular}{l|l}
\hline DOI: $10.1159 / 000369701$ & (C) 2015 S. Karger AG, Basel
\end{tabular}

Cui et al.: PM Impairs EPC via ROS Production

\section{References}

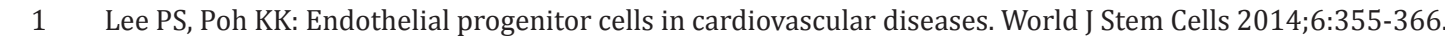

$\rightarrow 2$ Du F, Zhou J, Gong R, Huang X, Pansuria M, Virtue A, Li X, Wang H, Yang XF: Endothelial progenitor cells in atherosclerosis. Front Biosci 2012;17:2327-2349.

-3 Rauscher FM, Goldschmidt-Clermont PJ, Davis BH, Tang W, Gregg D, Ramaswami R, Pippen AM, Annex BH, Dong CM, Taylor DA: Aging, progenitor cell exhaustion, and atherosclerosis. Circulation 2003;108:457-463.

4 Urbich C, Dimmeler S: Endothelial progenitor cells: Characterization and role in vascular biology. Circ Res 2004;95:343-353.

5 Werner N, Kosiol S, Schiegl T, Ahlers P, Walenta K, Link A, Bohm M, Nickenig G: Circulating endothelial progenitor cells and cardiovascular outcomes. New Engl J Med 2005;353:999-1007.

6 Lim SS, Vos T, Flaxman AD, Danaei G, Shibuya K, Adair-Rohani H, Amann M, Anderson HR, Andrews KG, Aryee M, Atkinson C, Bacchus LJ, Bahalim AN, Balakrishnan K, Balmes J, Barker-Collo S, Baxter A, Bell ML, Blore JD, Blyth F, Bonner C, Borges G, Bourne R, Boussinesq M, Brauer M, Brooks P, Bruce NG, Brunekreef B, Bryan-Hancock C, Bucello C, Buchbinder R, Bull F, Burnett RT, Byers TE, Calabria B, Carapetis J, Carnahan E, Chafe Z, Charlson F, Chen H, Chen JS, Cheng AT, Child JC, Cohen A, Colson KE, Cowie BC, Darby S, Darling S, Davis A, Degenhardt L, Dentener F, Des Jarlais DC, Devries K, Dherani M, Ding EL, Dorsey ER, Driscoll T, Edmond K, Ali SE, Engell RE, Erwin PJ, Fahimi S, Falder G, Farzadfar F, Ferrari A, Finucane MM, Flaxman S, Fowkes FG, Freedman G, Freeman MK, Gakidou E, Ghosh S, Giovannucci E, Gmel G, Graham K, Grainger R, Grant B, Gunnell D, Gutierrez HR, Hall W, Hoek HW, Hogan A, Hosgood HD, 3rd, Hoy D, Hu H, Hubbell BJ, Hutchings SJ, Ibeanusi SE, Jacklyn GL, Jasrasaria R, Jonas JB, Kan H, Kanis JA, Kassebaum N, Kawakami N, Khang YH, Khatibzadeh S, Khoo JP, Kok C, Laden F, Lalloo R, Lan Q, Lathlean T, Leasher JL, Leigh J, Li Y, Lin JK, Lipshultz SE, London S, Lozano R, Lu Y, Mak J, Malekzadeh R, Mallinger L, Marcenes W, March L, Marks R, Martin R, McGale P, McGrath J, Mehta S, Mensah GA, Merriman TR, Micha R, Michaud C, Mishra V, Mohd Hanafiah K, Mokdad AA, Morawska L, Mozaffarian D, Murphy T, Naghavi M, Neal B, Nelson PK, Nolla JM, Norman R, Olives C, Omer SB, Orchard J, Osborne R, Ostro B, Page A, Pandey KD, Parry CD, Passmore E, Patra J, Pearce N, Pelizzari PM, Petzold M, Phillips MR, Pope D, Pope CA, 3rd, Powles J, Rao M, Razavi H, Rehfuess EA, Rehm JT, Ritz B, Rivara FP, Roberts T, Robinson C, Rodriguez-Portales JA, Romieu I, Room R, Rosenfeld LC, Roy A, Rushton L, Salomon JA, Sampson U, Sanchez-Riera L, Sanman E, Sapkota A, Seedat S, Shi P, Shield K, Shivakoti R, Singh GM, Sleet DA, Smith E, Smith KR, Stapelberg NJ, Steenland K, Stockl H, Stovner LJ, Straif K, Straney L, Thurston GD, Tran JH, Van Dingenen R, van Donkelaar A, Veerman JL, Vijayakumar L, Weintraub R, Weissman MM, White RA, Whiteford H, Wiersma ST, Wilkinson JD, Williams HC, Williams W, Wilson N, Woolf AD, Yip P, Zielinski JM, Lopez AD, Murray CJ, Ezzati M, AlMazroa MA, Memish ZA: A comparative risk assessment of burden of disease and injury attributable to 67 risk factors and risk factor clusters in 21 regions, 1990-2010: A systematic analysis for the global burden of disease study 2010. Lancet 2012;380:2224-2260.

-7 Brook RD, Rajagopalan S, Pope CA, 3rd, Brook JR, Bhatnagar A, Diez-Roux AV, Holguin F, Hong Y, Luepker RV, Mittleman MA, Peters A, Siscovick D, Smith SC, Jr., Whitsel L, Kaufman JD, American Heart Association Council on E, Prevention CotKiCD, Council on Nutrition PA, Metabolism: Particulate matter air pollution and cardiovascular disease: An update to the scientific statement from the american heart association. Circulation 2010;121:2331-2378.

-8 Brunekreef B, Forsberg B: Epidemiological evidence of effects of coarse airborne particles on health. Europ Respir J 2005;26:309-318.

-9 Brook RD, Urch B, Dvonch JT, Bard RL, Speck M, Keeler G, Morishita M, Marsik FJ, Kamal AS, Kaciroti N, Harkema J, Corey P, Silverman F, Gold DR, Wellenius G, Mittleman MA, Rajagopalan S, Brook JR: Insights into the mechanisms and mediators of the effects of air pollution exposure on blood pressure and vascular function in healthy humans. Hypertension 2009;54:659-667.

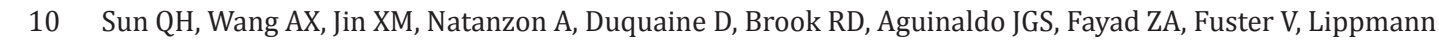
M, Chen LC, Rajagopalan S: Long-term air pollution exposure and acceleration of atherosclerosis and vascular inflammation in an animal model. Jama-J Am Med Assoc 2005;294:3003-3010.

-11 Liberda EN, Cuevas AK, Gillespie PA, Grunig G, Qu QS, Chen LC: Exposure to inhaled nickel nanoparticles causes a reduction in number and function of bone marrow endothelial progenitor cells. Inhal Toxicol 2010;22:95-99. 


\section{Cellular Physiology and Biochemistry}

Cell Physiol Biochem 2015;35:353-363

\begin{tabular}{l|l}
\hline DOI: $10.1159 / 000369701$ & (c) 2015 S. Karger AG, Basel
\end{tabular}

Cui et al.: PM Impairs EPC via ROS Production

12 Brook RD, Bard RL, Kaplan MJ, Yalavarthi S, Morishita M, Dvonch JT, Wang L, Yang HY, Spino C, Mukherjee B, Oral EA, Sun QH, Brook JR, Harkema J, Rajagopalan S: The effect of acute exposure to coarse particulate matter air pollution in a rural location on circulating endothelial progenitor cells: Results from a randomized controlled study. Inhal Toxicol 2013;25:587-592.

13 Khurshid SS, Siegel JA, Kinney KA: Indoor particulate reactive oxygen species concentrations. Envir Res 2014;132:46-53.

14 Nocun MS, Schantz MM: Determination of selected oxygenated polycyclic aromatic hydrocarbons (oxypahs) in diesel and air particulate matter standard reference materials (srms). Anal Bioanal Chem 2013;405:5583-5593.

-15 Mutlu GM, Green D, Bellmeyer A, Baker CM, Burgess Z, Rajamannan N, Christman JW, Foiles N, Kamp DW, Ghio AJ, Chandel NS, Dean DA, Sznajder JI, Budinger GR: Ambient particulate matter accelerates coagulation via an il-6-dependent pathway. J Clin Invest 2007;117:2952-2961.

-16 Shadie AM, Herbert C, Kumar RK: Ambient particulate matter induces an exacerbation of airway inflammation in experimental asthma: Role of interleukin-33. Clin Exp Immunol 2014;177:491-499.

17 Arantes-Costa FM, Lopes FD, Toledo AC, Magliarelli-Filho PA, Moriya HT, Carvalho-Oliveira R, Mauad T, Saldiva PH, Martins MA: Effects of residual oil fly ash (rofa) in mice with chronic allergic pulmonary inflammation. Toxicol Pathol 2008;36:680-686.

18 Ferraro SA, Yakisich JS, Gallo FT, Tasat DR: Simvastatin pretreatment prevents ambient particle-induced lung injury in mice. Inhal Toxicol 2011;23:889-896.

19 Alberg T, Nilsen A, Hansen JS, Nygaard UC, Lovik M: Nitrogen dioxide: No influence on allergic sensitization in an intranasal mouse model with ovalbumin and diesel exhaust particles. Inhal Toxicol 2011;23:268-276.

-20 Mysore TB, Shinkel TA, Collins J, Salvaris EJ, Fisicaro N, Murray-Segal LJ, Johnson LE, Lepore DA, Walters SN, Stokes R, Chandra AP, O'Connell PJ, d'Apice AJ, Cowan PJ: Overexpression of glutathione peroxidase with two isoforms of superoxide dismutase protects mouse islets from oxidative injury and improves islet graft function. Diabetes 2005;54:2109-2116.

-21 Mital R, Zhang W, Cai M, Huttinger ZM, Goodman LA, Wheeler DG, Ziolo MT, Dwyer KM, d'Apice AJ, Zweier JL, He G, Cowan PJ, Gumina RJ: Antioxidant network expression abrogates oxidative posttranslational modifications in mice. Am J Physiol Heart Circul Physiol 2011;300:H1960-1970.

22 Rosenkranz AR, Schmaldienst S, Stuhlmeier KM, Chen WJ, Knapp W, Zlabinger GJ: A microplate assay for the detection of oxidative products using 2',7'-dichlorofluorescin-diacetate. J Immunol Methods 1992;156:39-45.

-23 Jurczyszyn A, Zebzda A, Czepiel J, Perucki W, Bazan-Socha S, Cibor D, Owczarek D, Majka M: Geldanamycin and its derivatives inhibit the growth of myeloma cells and reduce the expression of the met receptor. J Cancer 2014;5:480-490.

24 Traverse JH: Effect of the use and timing of bone marrow mononuclear cell delivery on left ventricular function after acute myocardial infarction: The time randomized trial (vol 308, pg 2380, 2012). Jama-J Am Med Assoc 2013;309:343-343.

25 Gunther C, Martini E, Wittkopf N, Amann K, Weigmann B, Neumann H, Waldner MJ, Hedrick SM, Tenzer S, Neurath MF, Becker C: Caspase-8 regulates tnf-alpha-induced epithelial necroptosis and terminal ileitis. Nature 2011;477:335-339.

-26 Wang XJ, Kong KM, Qi WL, Ye WL, Song PS: Interleukin-1 beta induction of neuron apoptosis depends on p38 mitogen-activated protein kinase activity after spinal cord injury. Acta Pharmacol Sinica 2005;26:934942.

27 Brucker N, Moro AM, Charao MF, Durgante J, Freitas F, Baierle M, Nascimento S, Gauer B, Bulcao RP, Bubols GB, Ferrari PD, Thiesen FV, Gioda A, Duarte MM, de Castro I, Saldiva PH, Garcia SC: Biomarkers of occupational exposure to air pollution, inflammation and oxidative damage in taxi drivers. Sci Total Environ 2013;463-464:884-893.

-28 Ryan KA, Smith MF, Sanders MK, Ernst PB: Reactive oxygen and nitrogen species differentially regulate toll-like receptor 4-mediated activation of nf-kappa $\mathrm{b}$ and interleukin-8 expression. Infect Immun 2004;72:2123-2130.

29 Di Stefano R, Barsotti MC, Felice F, Magera A, Lekakis J, Leone A, Balbarini A: Smoking and endothelial progenitor cells: A revision of literature. Curr Pharm Des 2010;16:2559-2566. 


\section{Cellular Physiology and Biochemistry}

Cell Physiol Biochem 2015;35:353-363

\begin{tabular}{l|l}
\hline DOI: $10.1159 / 000369701$ & (c) 2015 S. Karger AG, Basel
\end{tabular}

Cui et al.: PM Impairs EPC via ROS Production

-30 Haberzettl P, Lee J, Duggineni D, McCracken J, Bolanowski D, O'Toole TE, Bhatnagar A, Conklin DJ: Exposure to ambient air fine particulate matter prevents vegf-induced mobilization of endothelial progenitor cells from the bone marrow. Environ Health Persp 2012;120:848-856.

-31 Heiss C, Amabile N, Lee AC, Real WM, Schick SF, Lao D, Wong ML, Jahn S, Angeli FS, Minasi P, Springer ML, Hammond SK, Glantz SA, Grossman W, Balmes JR, Yeghiazarians Y: Brief secondhand smoke exposure depresses endothelial progenitor cells activity and endothelial function. J Am Coll Cardiol 2008;51:17601771.

-32 Zhu BQ Heeschen C, Sievers RE, Karliner JS, Parmley WW, Glantz SA, Cooke JP: Second hand smoke stimulates tumor angiogenesis and growth. Cancer Cell 2003;4:191-196.

-33 O'Toole TE, Hellmann J, Wheat L, Haberzettl P, Lee J, Conklin DJ, Bhatnagar A, Pope CA: Episodic exposure to fine particulate air pollution decreases circulating levels of endothelial progenitor cells. Circ Res 2010;107:200-203.

-34 Shafer MM, Perkins DA, Antkiewicz DS, Stone EA, Quraishi TA, Schauer JJ: Reactive oxygen species activity and chemical speciation of size-fractionated atmospheric particulate matter from lahore, pakistan: An important role for transition metals. Journal of environmental monitoring : JEM 2010;12:704-715.

- 35 Xiao GG, Wang MY, Li N, Loo JA, Nel AE: Use of proteomics to demonstrate a hierarchical oxidative stress response to diesel exhaust particle chemicals in a macrophage cell line. J Biol Chem 2003;278:5078150790.

-36 Deng X, Zhang F, Wang L, Rui W, Long F, Zhao Y, Chen D, Ding W: Airborne fine particulate matter induces multiple cell death pathways in human lung epithelial cells. Apoptosis 2014;19:1099-1112.

37 Xu Z, Xu X, Zhong M, Hotchkiss IP, Lewandowski RP, Wagner JG, Bramble LA, Yang Y, Wang A, Harkema JR, Lippmann M, Rajagopalan S, Chen LC, Sun Q: Ambient particulate air pollution induces oxidative stress and alterations of mitochondria and gene expression in brown and white adipose tissues. Part Fibre Toxicol 2011;8:20.

-38 Delfino RJ, Staimer N, Tjoa T, Gillen DL, Schauer JJ, Shafer MM: Airway inflammation and oxidative potential of air pollutant particles in a pediatric asthma panel. J Exp Sci Envir Epidem 2013;23:466-473.

-39 Tonne C, Yanosky JD, Beevers S, Wilkinson P, Kelly FJ: Pm mass concentration and pm oxidative potential in relation to carotid intima-media thickness. Epidemiology 2012;23:486-494.

-40 Godri KJ, Green DC, Fuller GW, Dall'Osto M, Beddows DC, Kelly FJ, Harrison RM, Mudway IS: Particulate oxidative burden associated with firework activity. Envir Scie Technol 2010;44:8295-8301.

-41 Strak M, Janssen NAH, Godri KJ, Gosens I, Mudway IS, Cassee FR, Lebret E, Kelly FJ, Harrison RM, Brunekreef B, Steenhof M, Hoek G: Respiratory health effects of airborne particulate matter: The role of particle size, composition, and oxidative potential-the raptes project. Environ Health Perspect 2012;120:1183-1189.

-42 Ardestani S, Deskins DL, Young PP: Membrane tnf-alpha-activated programmed necrosis is mediated by ceramide-induced reactive oxygen species. Journal of molecular signaling 2013;8:12.

43 Mokgobu MI, Cholo MC, Anderson R, Steel HC, Motheo MP, Hlatshwayo TN, Tintinger GR, Theron AJ: Oxidative induction of pro-inflammatory cytokine formation by human monocyte-derived macrophages following exposure to manganese in vitro. J Immunotoxicol 2014

44 Lee IT, Yang CM: Role of nadph oxidase/ros in pro-inflammatory mediators-induced airway and pulmonary diseases. Biochem Pharmacol 2012;84:581-590.

-45 Santee SM, OwenSchaub LB: Human tumor necrosis factor receptor p75/80 (cd120b) gene structure and promoter characterization. J Biol Chem 1996;271:21151-21159.

-46 Koike E, Hirano S, Furuyama A, Kobayashi T: Cdna microarray analysis of rat alveolar epithelial cells following exposure to organic extract of diesel exhaust particles. Toxicol Appl Pharm 2004;201:178-185.

-47 Romieu I, Tellez-Rojo MM, Lazo M, Manzano-Patino A, Cortez-Lugo M, Julien P, Belanger MC, HernandezAvila M, Holguin F: Omega-3 fatty acid prevents heart rate variability reductions associated with particulate matter. Am J Respir Critical Care Med 2005;172:1534-1540.

48 Tashakkor AY, Chow KS, Carlsten C: Modification by antioxidant supplementation of changes in human lung function associated with air pollutant exposure: A systematic review. Bmc Public Health 2011;11:532.

49 Turgeon J, Dussault S, Haddad P, Groleau J, Menard C, Michaud SE, Maingrette F, Rivard A: Probucol and antioxidant vitamins rescue ischemia-induced neovascularization in mice exposed to cigarette smoke: Potential role of endothelial progenitor cells. Atherosclerosis 2010;208:342-349. 